\title{
INTERNET MERETAS KEBUNTUAN ADMINISTRASI DESA CIBUNTU, PURWAKARTA
}

\author{
Indra Arifin Djashan $^{1 *}$, Dicky Supriatna ${ }^{\text {*** }}$ \\ ${ }^{I}$ STIE Trisakti, Jakarta \\ Penulis Korespodensi : *indra@stietrisakti.ac.id \\ **dicky@stietrisakti.ac.id
}

\begin{abstract}
Abstrak
Sustainable Development Goals (SDGs) merupakan agenda pembangunan dunia yang dipelopori oleh Perserikatan Bangsa-Bangsa (UN) memiliki tujuan bagi kesejahteraan umat manusia, dan melestarikan kehidupan bumi. Dengan mengacu kepada tujuan ke 4 dari tujuh belas tujuan SDG, yakni: menjamin pendidikan yang inklusif dan berkeadilan serta mendorong kesempatan belajar seumur hidup bagi semиa orang. Sebagian besar mata pencaharian penduduk di desa tersebut adalah petani. Beberapa komoditas utama seperti pala, gula aren dan manggis menjadi industri rumah tangga yang kerap menjadi andalan desa tersebut. Pusat Penelitian dan Pengabdian kepada Masyarakat (P3M) STIE Trisakti bekerja sama dengan SMA Lab School Kebayoran dimana P3M berkontribusi dalam hal pengadaan dan pelatihan dasar komputer. Permasalahan yang dihadapi oleh pengelola desa Cibuntu adalah pemanfaatan teknologi sebagai sarana dalam kegiatan administrasi yang cepat, mudah dan efisien. Metode pengabdian masyarakat yang diterapkan meliputi: ceramah, presentasi, studi kasus, simulasi dan evaluasi. Tujuan pengabdian masyarakat memberikan pelatihan dan penyuluhan akses kecepatan sambungan internet, instalasi jaringan sederhana, dan penanganan atas serangan virus dengan harapan pekerjaan administrasi dan laporan perkembangan desa dapat diaplikasikan dengan mudah dan cepat. Target dan luaran yang hendak dicapai adalah membangun infrastruktur jaringan sederhana, mendorong kesempatan belajar bagi setiap warga desa, dan membina inovasi yang berkelanjutan. Tentunya bukan sekedar ilmu dan pengetahuan yang disampaikan, tetapi juga bantuan dua unit komputer sebagai wujud untuk kemudahan bagi perangkat desa Cibuntu dalam melaksanakan kegiatan operasional sehari-hari.
\end{abstract}

Kata kunci: Sustainable Development Goals, Desa Cibuntu Purwakarta, STIE Trisakti, Pengabdian Masyarakat, P3M

\section{Pendahuluan}

Salah satu fungsi P3M adalah membantu masyarakat dalam melaksanakan pembangunan, terutama dalam hal pengembangan SDM. Program SDGs dengan jelas, terutama pada tujuan nomor 4, menjamin pendidikan yang inklusif dan berkeadilan serta mendorong kesempatan belajar seumur hidup bagi semua orang[4]. Sehingga dosen memiliki tantangan dan tanggungjawab bagaimana menjadi saluran bagi masyarakat terutama di daerah yang membutuhkan. Undangan untuk bekerjasama datang dari SMA Lab. School Kebayoran dalam program Live-in siswa di desa Cibuntu, Purwakarta[5]. Desa Cibuntu mempunyai luas wilayah sebesar 124,25 Ha. Desa Cibuntu merupakan desa yang berbukit dengan ketinggian \pm 650 meter diatas permukaan laut. Oleh karena itu, Desa Cibuntu bersuhu sejuk antara $23-30^{\circ} \mathrm{C}$. Masyarakat Desa Cibuntu bermata pencaharian utama sebagai buruh tani, petani, dan peternak.
Dengan melihat dan mencermati kebutuhan pengembangan SDM dan infrastruktur teknologi informasi, maka $\mathrm{P} 3 \mathrm{M}$ berinisiatif untuk turut berkontribusi dalam kegiatan program pengabdian kepada masyarakat.

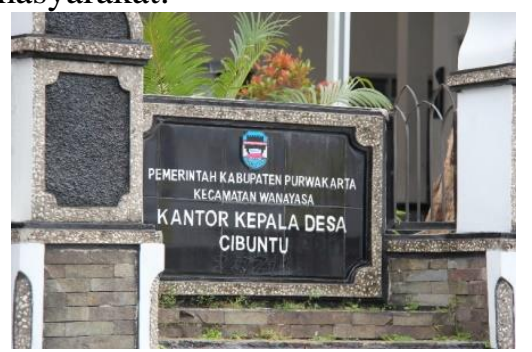

Gambar 1. Tampak Depan Kantor Kepala Desa

Permasalahan utama yang dihadapi oleh pengelola desa Cibuntu adalah pemanfaatan teknologi sebagai sarana dalam kegiatan administrasi yang cepat, mudah dan efisien. Sehingga peran pemerintah daerah dalam menyediakan sarana infrastruktur teknologi 
informasi sangat dibutuhkan oleh masyarakat di pedesaan dalam melakukan kegiatan administrasi di kantor kepala desa. Menurut informasi yang didapatkan bahwa, sambungan internet seringkali terputus dan seringkali tidak ada sinyal kuat di waktu-waktu tertentu.

Tidak dapat dipungkiri bahwa ketersediaan dan kecepatan internet yang memadai menjadi sarana penting dalam komunikasi dan pekerjaan seharihari. Sehingga berdasar-kan kebutuhan dan masalah tersebut, tim pengabdian masyarakat melalui P3M melakukan identifikasi, analisa, implementasi dan evaluasi[2] terhadap permasalah diatas.

\section{Metode}

Materi yang dipersiapkan selama pengabdian masyarakat adalah: administrasi surat- menyurat, LCD projektor, notebook, dokumentasi, bahan presentasi (ppt) dan handsout. Berdasarkan informasi dan hasil wawancara yang dilakukan sebelum melakukan pengabdian masyarakat, ada kebutuhan di desa Cibuntu untuk pengadaan komputer. Maka P3M mengupayakan sehingga ada sumbangan dua unit PC komputer dan perlengkapan alat jejaring.

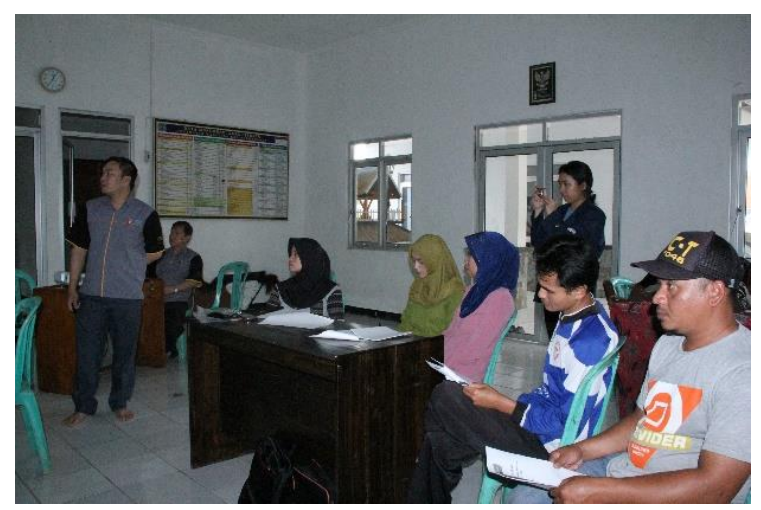

Gambar 2. Suasana pada saat presentasi Pelatihan

Metode yang diterapkan dalam pelatihan di desa Cibuntu, Purwakarta meliputi: ceramah, presentasi, studi kasus, simulasi dan evaluasi. Ceramah dan presentasi dilakukan melalui pendekatan diskusi dan media power point dengan memberikan pengenalan teori dasar-dasar komputer, pengenalan perangkat keras, instalasi jaringan komputer sederhana dan penanganan virus. Sementara semua yang disampaikan materi presentasi juga diberikan handsout sehingga peserta dapat mengikuti dengan baik. Tidak cukup hanya teori, trainer juga menyampaikan dengan memberikan contoh studi kasus untuk memudahkan pengertian dan penjelasan teori yang sudah disampaikan diawal pertemuan. Peserta tampak antusias dan banyak bertanya seputar permasalahan jaringan komputer dan hambatan oleh virus komputer.

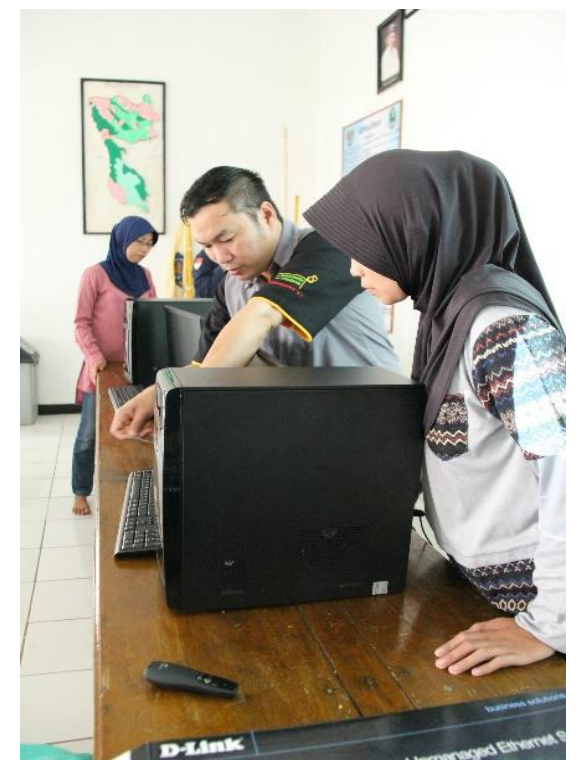

Gambar 3. Simulasi Instalasi Jaringan Komputer

Selanjutnya trainer memberikan simulasi berupa instalasi jejaring sederhana. Peserta diminta sebagai volunteer untuk hands on pada komputer yang sudah disiapkan. Masing-masing mencoba melakukan sesuai petunjuk di materi dari awal hingga selesai. Tentunya dibantu oleh trainer dan mahasiswa lainnya. Pada sesi simulasi, waktu terasa lambat, karena peserta melakukan uji coba dengan teori yang sudah dijelaskan.

Pelajaran terbaik adalah dengan melakukan. Lebih dari 2.500 tahun yang lalu Confucius memperhatikan, "saya mendengar dan saya lupa, saya melihat dan saya ingat. Saya mengerjakan dan saya mengerti”. Sebagian besar pendidik mengakui bahwa pemahaman dan wawasan terdalam kita berasal dari tindakan, diikuti oleh refleksi dan pencarian untuk perbaikan[1]. Konsep learning by doing diterapkan dengan harapan peserta dapat memahami materi yang disampaikan, sehingga mampu memberikan solusi terhadap masalah yang dihadapi.

Pada sesi terakhir, trainer melakukan evaluasi sederhana dengan tujuan untuk mendapatkan feed back dari peserta. Melalui pertanyaan dan kesimpulan materi, maka pelatihan 
ini diharapkan dapat meretas kebuntuan pada administrasi di desa Cibuntu, Purwakarta.

\section{Hasil dan Pembahasan}

Hasil dari kegiatan pengabdian masyarakat dalam bentuk pelatihan dasar dan pengadaan komputer di desa Cibuntu, Purwakarta adalah kemampuan dan pengetahuan peserta mengenai instalasi jaringan sederhana dan mengatasi masalah virus di tingkat dasar. Bantuan P3M berupa komputer sebanyak 2 (dua) unit diharapkan dapat membantu untuk menyelesaikan masalah administrasi surat menyurat dan akses informasi via internet secara memadai. Setidaknya aparat dan pengelola kantor kepala desa Cibuntu dapat menyelesaikan persoalan administrasi yang dibutuhkan oleh masyarakat setempat dengan cepat dan tanggap. Penggunaan sumber daya perangkat keras seperti printer dan alat pemindai (scanner) dapat diminimalisasikan dengan kehadiran jejaring komputer, dengan demikian efisiensi biaya dan waktu dapat dicapai.

Jejaring komputer adalah sebuah sistem yang menghubungkan komputer dan semua peralatannya (contoh: printer) melalui media komunikasi sehingga data dan informasi dapat ditranmisikan diantara mereka[3].

Untuk mencapai tujuan ke-empat dari tujuh belas tujuan SDGs, yakni: menjamin pendidikan yang inklusif dan berkeadilan serta mendorong kesempatan belajar seumur hidup bagi semua orang[5], maka P3M STIE Trisakti telah berupaya agar masyarakat desa Cibuntu, Purwakarta turut merasakan kemajuan teknologi melalui pemberdayaan dan pemanfaatan internet sebagai salah satu upaya mencerdaskan kehidupan bangsa dan negara.

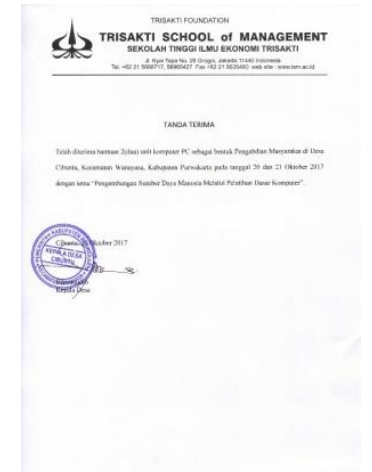

Gambar 4. Tanda Terima Bantuan Komputer

\section{Kesimpulan dan Saran}

Melalui Tridharma perguruan tinggi dan program pemerintah khususnya Kemenristekdikti, mendorong dan memotivasi dosen melalui lembaga penelitian dan pengabdian masyarakat untuk dapat berbuat "banyak" kepada masyarakat yang membutuhkan. P3M STIE Trisakti belum banyak memberikan kontribusi penting, tetapi diyakini bahwa setiap langkah kegiatan selalu diawali dengan ketulusan dan harapan agar hasil akhir memberikan nilai kepada masyarakat yang menerima bantuan dan pengabdian masyarakat P3M. Pemerintah daerah, khususnya Jawa Barat belum secara maksimal menyediakan infrastruktur internet yang memadai di daerah pedesaan sehingga informasi dan akses ke pemerintah pusat tidak dapat dilakukan dengan mudah dan cepat. Percepatan pelayanan menuntut infrastruktur yang makin modern dan mutakhir. P3M STIE Trisakti salah satu perguruan tinggi swasta yang merupakan kepanjangan tangan dari Pendidikan Tinggi untuk menjawab dan memberikan solusi terhadap masalah yang dihadapi masyarakat pedesaan. Bahu membahu untuk membangun masyarakat di pedesaan membutuhkan orang-orang terampil dan cakap, dengan demikian kemajuan juga dirasakan di berbagai wilayah daerah.

Penulis berharap bahwa pengabdian masyarakat tidak berhenti disini, tetapi tetap dilanjutkan dengan program yang berkesinambungan. Dengan harapan desa Cibuntu, Purwakarta akan menjadi salah satu desa binaan bagi STIE Trisakti dan menjadi contoh bagi desa lainnya.

Semoga desa Cibuntu, Purwakarta mendapatkan pengetahuan dan pengembangan SDM yang lebih baik setelah selesainya pengabdian masyarakat dalam bentuk pelatihan. Dan tema PKM-CSR yakni: "Optimalisasi Peran Perguruan Tinggi dan Dunia Usaha Dalam Mencapai SDGs" dapat terwujud dan terlaksana.

\section{Ucapan Terima Kasih}

Kegiatan pengabdian masyarakat ini dapat terlaksana berkat dukungan dan bantuan dari Kepala Desa Cibuntu, Purwakarta, Bapak Ikhwanudin; Kepala Sekolah SMA Lab. School Kebayoran Jakarta, Bapak Drs. Risang Danardana L.,MM.; Kepala Program Studi Jurusan Manajemen STIE Trisakti, Ibu Dr. Nurwanti,MM.; dan Pusat Penelitian \& Pengabdian kepada Masyarakat (P3M) STIE Trisakti. Terima kasih, 
semoga Tuhan Yang Maha Esa memberikan balasan kepada kebaikan Bapak dan Ibu yang sudah banyak memberikan dukungan serta bantuan sehingga kegiatan pengabdian dan artikel ini dapat terwujud dengan lancar dan diseminarkan pada PKM-CSR 2018.

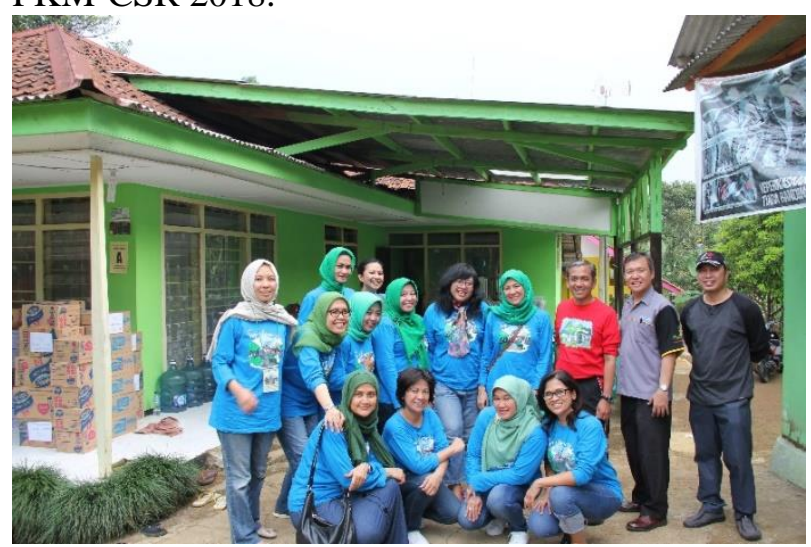

Gambar 5. Foto bersama Kepala Sekolah dan Guru SMA Lab. School Kebayoran

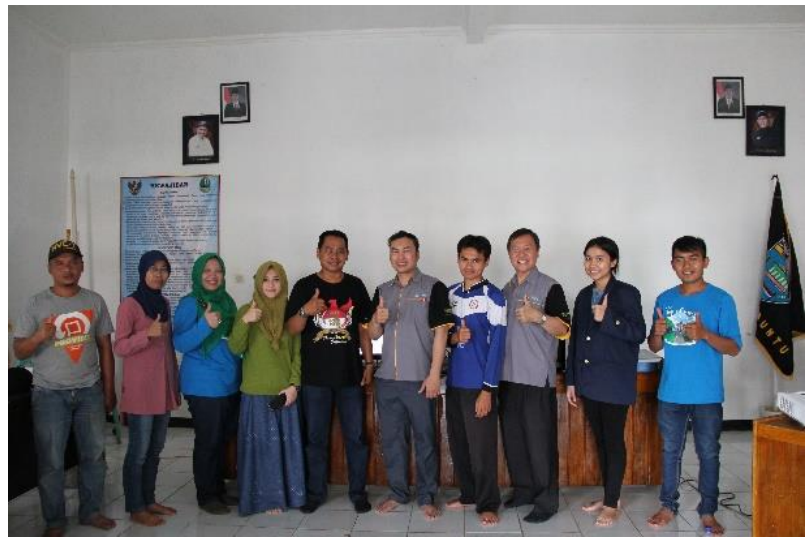

Gambar 6. Foto bersama Kepala Desa dan Peserta Pelatihan di Kantor Kepala Desa Cibuntu

\section{Daftar Pustaka}

DuFour, R., and DuFour, R. 2016. Learning by Doing: A Handbook for Professional Learning Communities at Work TM. Second edition. Solution Tree Press.

Romney, Marshall B., and Steinbart, Paul J. 2013. Accounting Information Systems. 13rd edition. Pearson.

Rainer, Prince et all. 2015. Introduction to Information Systems. $5^{\text {th }}$ edition. Wiley

https://sustainabledevelopment.un.org/sdgs diakses tanggal 3 September 2018

http://www.labschool-unj.sch.id/smakebayoran/201310-08-00-39-40/sdm.html diakses tanggal 4 September 2018. 